DOI: https://doi.org/10.35961/jppmkepri.v1i2.299

\title{
An Analysis of Pronunciation Errors in Speaking Of 2nd Semester Students of English Educate Department Universitas Bhinneka PGRI
}

\author{
Baiq Titis Lidyawaty ${ }^{1 *}$, Ayu Rizki Septiana ${ }^{2}$ \\ ${ }^{1,2}$ University of Bhinneka PGRITulungagung, Indonesia \\ * lidyawaty98@gmail.com
}

\begin{abstract}
In this study, researchers will examine students' problems in pronunciation errors in English and the causes of students' errors in English pronunciation. This study aims to determine the pronunciation errors and the causes of errors in pronunciation made by students in speaking English. This research is descriptive qualitative research that aims to describe students' pronunciation errors and the causes of students' pronunciation errors. The subjects of this study were secondsemester students of the English language study program at the University of Bhinneka PGRI. The reason the researcher chooses this subject is the first subject that the researcher wants to examine and understand because there are some students who experience pronunciation errors and the researcher wants to know where the pronunciation errors are and what causes make their pronunciation errors. Based on the results of observations, the researchers found that students' problems in speaking English were in the vowel they were stamped. The results of the questionnaire that the researchers distributed from the entire 2nd-semester class, both class $2 A$ and class $2 B$, totaling 44 students, received answers from 39 students. The results obtained from 10 interviews researchers can conclude that there are several causes of difficulty or pronunciation errors in semester 2 students at the Universitas Bhinneka PGRI including Mother Language and Personality.
\end{abstract}

Keywords: Pronunciation errors; factors of pronunciation errors

\section{Introduction}

It is generally known that English is an international language. English has an important role as an international communication language that can connect people from various countries. English is used by people to communicate with other people in different countries. As a result, using English as an international communication is effective for connecting people to communicate. In the era of globalization, students have returned to mastering English as a means of communication. Students majoring in English at the Universitas Bhninneka PGRI, for example, must master all components of skills and English. There are some mistakes that are usually made by students in using English, especially in speaking. The demands of this modern 
world require communication skills for students and English teachers to teach the necessary skills to enable them to improve their speaking skills and perform well in real life situations (Ramasari, 2017).

In this era of globalization, it has an impact on the learning and teaching of a second language, which is none other than the function of English as an international language tool or as a lingua franca (ELF) for communication that needs to be rethought in English. After realizing the importance of communication, now

more emphasis is placed on developing students' speaking skills. Students are required to master and focus on speaking skills with the correct accent. Here the teacher plays an important role as the teacher can help students develop the linguistic skill lines necessary to understand different types of accents and in turn be understood by others. Therefore, it is imperative for teachers to respond appropriately to equip their students with the skills needed to deal with the emerging cultures and languages among intermediaries in the international world.

The causes of pronunciation errors can affect the meaning of the spoken word. Most of the errors that often occur by students are due to phonological, lexical, and vocal errors, students also produce sound quality errors in pronunciation, rhythm, and intonation (Hassan Al-Ahdal, Al-Hattami, Al-Awaid, \& AlMashaqba, 2015). Therefore, this view challenges researchers to conduct research to uncover various pronunciation errors of English words for second semester students, because the authors realize that accurate pronunciation is very important to support students' learning to identify English pronunciation errors while speaking and classify based on the type of error.

The results of observations made by second semester students of English study program at Universitas Bhinneka PGRI that pronunciation errors that occur in students are vocal and phonetic, while the cause of errors is caused by the mother tongue and student personality. a writer does research entitled: "An Analysis of Pronunciation Errors in Speaking Of 2nd Semester Students of English Educate Department Universitas Bhinneka PGRI"

\section{Method}

This study used descriptive qualitative method. The researcher wants to show students' pronunciation errors and the causes of students' pronunciation errors. This study focuses on deciphering the pronunciation errors made by second semester students of English study program.The researcher will show the wrong words spoken by the students and describe the causes of the mispronunciation of the research subject.

The main subjects of this research are second semester students of English study program at the Universitas Bhinneka PGRI. Researchers chose several subjects in this study. The activity that researchers do is analysis. In the analysis, the researcher tried to collect as much data as possible. In analyzing the data, the researcher saw and listened to audio and video from students through voice notes and google drives sent by students. In this study, researchers also used a transcription application combined with a phonetic transcript.

The main data for this study were collected through the following procedure. First, the researcher gavea test in the form of short stories to be submitted by students and how to collect the data, the subject sent recordings and videos to be analyzed. Second, after the data was collected, the researcher analyzed the video using transcription, phonetic transcription and the researcher also matched it with the parameters that the researcher had provided. Third, the researchers also distributed questionnaires and interviews to find out the difficulties and causes of students' pronunciation errors. Fourth, with the data collected, the researcher can draw conclusions from pronunciation errors and describe the errors and causes of errors. 


\section{The Findings}

The result and the finding of the research that was already conducted in Universitas Bhinneka PGRI. There would be two subchapters based on the topic above. They are Research finding which tells about data found during the research and Discussion which explains about the description of data in research finding.

\section{Vowels}

The results of the researchers' observations found pronunciation errors from 6 subjects that the researchers used in data collection, the results data collection researchers found pronunciation errors, one of which was Vowels. Vowel Pronunciation Errors From these data, the researcher found several mistakes made by six students of the English study program at the Universitas Bhinneka PGRI in pronouncing English vowels. From the results of the study, there were several vowel pronounciation errors in students, namely long vowels and short vowels. below will be explained through the error distribution table:

Table 1

Errors of Long Vowels

\begin{tabular}{|c|c|c|c|c|c|c|}
\hline No & Word & $\begin{array}{c}\text { Correct } \\
\text { Phonetic } \\
\text { Transcription }\end{array}$ & $\begin{array}{c}\text { Transcription of } \\
\text { Student's } \\
\text { Pronunciation }\end{array}$ & Errors & Freq & Percentage \\
\hline 1 & She & / $\mathrm{ji}: /$ & $/ \mathrm{se} /$ & /e/ & 3 & $50 \%$ \\
\hline \multirow[t]{5}{*}{2} & \multirow[t]{5}{*}{ People } & \multirow[t]{5}{*}{ /"epi:pl/ } & /peple/ & /e/ & 1 & $16,6 \%$ \\
\hline & & & /pepel/ & /e/ & 1 & $16,6 \%$ \\
\hline & & & /pepple/ & /e/ & 1 & $16,6 \%$ \\
\hline & & & $/ \mathrm{p} \underline{\Delta} \mathrm{p} ə \mathrm{l} /$ & $/ \mathrm{N} /$ & 1 & $16,6 \%$ \\
\hline & & & /poupəl/ & $/ \mho /$ & 2 & $33,3 \%$ \\
\hline 3 & $\mathrm{Me}$ & /mi:/ & $/ \mathrm{me} /$ & /e/ & 2 & $33,3 \%$ \\
\hline 4 & Sweet & Sweet & $/ \mathrm{swet} /$ & /e/ & 2 & $33,3 \%$ \\
\hline
\end{tabular}

Table 2

Table Errors Of Long Vowels 1

\begin{tabular}{|c|c|c|c|c|c|c|}
\hline No & Word & $\begin{array}{c}\text { Correct } \\
\text { Phonetic } \\
\text { Transcription }\end{array}$ & $\begin{array}{l}\text { Transcription of } \\
\text { Student's } \\
\text { Pronunciation }\end{array}$ & Errors & Freq & Percentage \\
\hline \multirow[t]{2}{*}{1} & \multirow{2}{*}{$\begin{array}{c}\text { Perso } \\
n\end{array}$} & \multirow[t]{2}{*}{ /"ep3:sn/ } & $/ \mathrm{p} \underline{\mathbf{e}}(\mathrm{r}) \operatorname{sen} /$ & /e/ & 3 & $50 \%$ \\
\hline & & & $/ \mathrm{p} \underline{\mathbf{e}}(\mathrm{r}) \operatorname{spn} /$ & /e/ & 2 & $33,3 \%$ \\
\hline \multirow[t]{3}{*}{2} & \multirow[t]{3}{*}{ Curly } & \multirow[t]{3}{*}{ /"ek3:li/ } & $/ \mathrm{k}_{\underline{\Lambda}}(\mathrm{r}) \mathrm{li} /$ & $/ \mathrm{N} /$ & 4 & $66,6 \%$ \\
\hline & & & /kㅁ⒭li/ & $/ \mho /$ & 1 & $16,6 \%$ \\
\hline & & & $/ \mathrm{t} \underline{\underline{\sigma}}(\mathrm{r}) \mathrm{li} /$ & $/ \mho /$ & 1 & $16,6 \%$ \\
\hline 3 & Her & /h3:r/ & /hIr/ & $/ \mathrm{I} /$ & 3 & $50 \%$ \\
\hline
\end{tabular}


Table 3

Table Errors Of Long Vowels 2

\begin{tabular}{|c|c|c|c|c|c|c|}
\hline No & Word & $\begin{array}{c}\text { Correct } \\
\text { Phonetic } \\
\text { Transcription }\end{array}$ & $\begin{array}{c}\text { Transcription } \\
\text { of Student's } \\
\text { Pronunciation }\end{array}$ & Errors & Freq & Percentage \\
\hline \multirow[t]{2}{*}{1} & \multirow[t]{2}{*}{ Tall } & \multirow[t]{2}{*}{$/ \mathrm{t}$ o:1/ } & $/$ tel// & $/ \mathrm{e} /$ & 3 & $50 \%$ \\
\hline & & & $/ t_{\underline{\Lambda}} \mathrm{l} /$ & $/ \mathrm{N} /$ & 2 & $33,3 \%$ \\
\hline 2 & Short & $/ \int 0: t /$ & $/ \mathrm{s} \underline{\mathbf{z}}(\mathrm{r}) \mathrm{t} /$ & $/ \mathrm{p} /$ & 3 & $50 \%$ \\
\hline \multirow[t]{2}{*}{3} & \multirow[t]{2}{*}{ Always } & \multirow[t]{2}{*}{ /eeo:lweiz/ } & /slwaiz/ & $/ \mathrm{N} /$ & 4 & $66,6 \%$ \\
\hline & & & /elweiz/ & /e/ & 2 & $33,3 \%$ \\
\hline
\end{tabular}

Table 4

Table Errors Of Long Vowels 3

\begin{tabular}{|c|c|c|c|c|c|c|}
\hline No & Word & $\begin{array}{c}\text { Correct } \\
\text { Phonetic } \\
\text { Transcription }\end{array}$ & $\begin{array}{l}\text { Transcription } \\
\text { of Student's } \\
\text { Pronunciation }\end{array}$ & Errors & Freq & Percentage \\
\hline \multirow[t]{3}{*}{1} & \multirow[t]{3}{*}{ Example } & \multirow{3}{*}{ /Ig'za:mpl/ } & /eg'zımpəl// & $/ \Lambda /$ & 3 & $50 \%$ \\
\hline & & & /eg'zempəl/ & /e/ & 1 & $16,6 \%$ \\
\hline & & & /eg'zample/ & $/ \Lambda /$ & 2 & $33,3 \%$ \\
\hline
\end{tabular}

Table 5

Table Errors Of Long Vowels 5

\begin{tabular}{|c|c|c|c|c|c|c|}
\hline No & Word & $\begin{array}{c}\text { Correct } \\
\text { Phonetic } \\
\text { Transcription }\end{array}$ & $\begin{array}{c}\text { Transcription } \\
\text { of Student's } \\
\text { Pronunciation }\end{array}$ & Errors & Freq & Percentage \\
\hline 1 & Beautiful & $/$ /ebju:təful/ & $/$ bettful/ & $/ \mathrm{e} /$ & 4 & $66,6 \%$ \\
\cline { 4 - 7 } & & $/ \mathrm{b}$ e $\Lambda \mathrm{ttfful} /$ & $/ \mathrm{N} /$ & 2 & $33,3 \%$ \\
\hline 2 & To & $/ \mathrm{tu} / /$ & $/ \mathrm{tp} /$ & $/ \mathrm{p} /$ & 2 & $33,3 \%$ \\
\hline
\end{tabular}

Table 6

Table Errors on Short Vowels 1

\begin{tabular}{|c|c|c|c|c|c|c|}
\hline No & Word & $\begin{array}{c}\text { Correct } \\
\text { Phonetic } \\
\text { Transcription }\end{array}$ & $\begin{array}{l}\text { Transcription } \\
\text { of Student's } \\
\text { Pronunciation }\end{array}$ & Errors & Freq & Percentage \\
\hline \multirow[t]{3}{*}{1} & \multirow[t]{3}{*}{ Because } & \multirow[t]{3}{*}{ /bi'kbz/ } & /be' 'yauz/ & /e/ & 2 & $33,3 \%$ \\
\hline & & & /be'kpz/ & $/ e /$ & 2 & $33,3 \%$ \\
\hline & & & /be'tyz/ & /e/ & 2 & $33,3 \%$ \\
\hline 2 & Honey & /hıni/ & /hpne// & /e/ & 2 & $33,3 \%$ \\
\hline 3 & Example & /ıg'za:mpl/ & /eg'zımpəl/ & /e/ & 3 & $50 \%$ \\
\hline
\end{tabular}




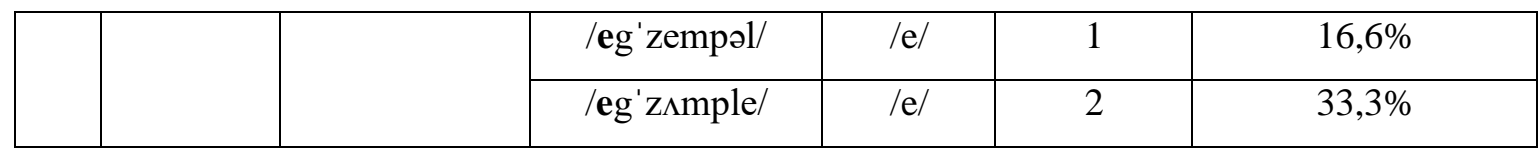

Table 7

Table Errors on Short Vowels 2

\begin{tabular}{|c|c|c|c|c|c|c|}
\hline No & Word & $\begin{array}{c}\text { Correct } \\
\text { Phonetic } \\
\text { Transcription }\end{array}$ & $\begin{array}{l}\text { Transcription } \\
\text { of Student's } \\
\text { Pronunciation }\end{array}$ & Errors & Freq & Percentage \\
\hline 1 & Mother & /"emıðə/ & /mpðe(r)/ & /e/ & 4 & $66,6 \%$ \\
\hline 2 & Color & $/{ }^{\circ e} \mathrm{k} \Lambda \mathrm{l} / \mathrm{s} /$ & /kplpr/ & $/ \mathrm{p} /$ & 6 & $100 \%$ \\
\hline 3 & Patient & /"epeifont & /pstient/ & $/ \mathrm{I} /$ & 3 & $50 \%$ \\
\hline & & & /petient/ & $/ \mathrm{I} /$ & 2 & $33,3 \%$ \\
\hline
\end{tabular}

Table 7

Table Errors on Short Vowels 3

\begin{tabular}{|l|c|c|c|c|c|c|}
\hline No & Word & $\begin{array}{c}\text { Correct } \\
\text { Phonetic } \\
\text { Transcription }\end{array}$ & $\begin{array}{c}\text { Transcription } \\
\text { of Student's } \\
\text { Pronunciation }\end{array}$ & Errors & Freq & Percentage \\
\hline 1 & \multirow{2}{*}{ Friendly } & $/{ }^{\circ e}$ frendli/ & $/$ fraIndli/ & $/$ aI/ & 2 & $33,3 \%$ \\
\cline { 3 - 7 } & & & $/$ frindli/ & $/ \mathrm{I} /$ & 1 & $16,6 \%$ \\
\cline { 4 - 7 } & & & $/$ frrendli/ & $/ \mathrm{Ie} /$ & 3 & $50 \%$ \\
\hline
\end{tabular}

Table 8

Table Errors on Short Vowels 4

\begin{tabular}{|c|c|c|c|c|c|c|}
\hline No & Word & $\begin{array}{c}\text { Correct } \\
\text { Phonetic } \\
\text { Transcription }\end{array}$ & $\begin{array}{c}\text { Transcription } \\
\text { of Student's } \\
\text { Pronunciation }\end{array}$ & Errors & Freq & Percentage \\
\hline 1 & Has & $/ \mathrm{hæz} /$ & $/ \mathrm{h} \Lambda \mathrm{S} /$ & $/ \mathrm{N} /$ & 2 & $33,3 \%$ \\
\hline 2 & Family & $/$ fæmıli $/$ & $/ \mathrm{f} \Lambda \mathrm{mIl} / /$ & $/ \mathrm{N} /$ & 4 & $66,6 \%$ \\
\hline
\end{tabular}


Table 8

Table Errors on Short Vowels 5

\begin{tabular}{|c|c|c|c|c|c|c|}
\hline No & Word & $\begin{array}{c}\text { Correct } \\
\text { Phonetic } \\
\text { Transcription }\end{array}$ & $\begin{array}{l}\text { Transcription } \\
\text { of Student's } \\
\text { Pronunciation }\end{array}$ & Errors & Freq & Percentage \\
\hline 1 & Mother & $/ \mathrm{m} \wedge$ ठə/ & /mpðer/ & $/ \mathrm{p} /$ & 3 & $50 \%$ \\
\hline 2 & But & $/ \mathrm{b} \Lambda \mathrm{t} /$ & /bot/ & $/ \mho /$ & 2 & $33,3 \%$ \\
\hline 3 & Color & /kılər/ & /knlpr/ & $/ \mathrm{p} /$ & 3 & $50 \%$ \\
\hline \multirow[t]{3}{*}{4} & \multirow[t]{3}{*}{ Honey } & \multirow[t]{3}{*}{ /hıni/ } & /heni/ & /e/ & 2 & $33,3 \%$ \\
\hline & & & /hpni/ & $/ \mathrm{p} /$ & 3 & $50 \%$ \\
\hline & & & /hwneI/ & $/ \mathrm{p} /$ & 3 & $50 \%$ \\
\hline 5 & Lovely & /"ec $1 \Lambda \mathrm{vli} /$ & /lpvli/ & $/ \mathrm{p} /$ & 4 & $66,6 \%$ \\
\hline \multirow[t]{2}{*}{6} & \multirow[t]{2}{*}{ Loves } & \multirow[t]{2}{*}{$/ 1 \Lambda \mathrm{VZ} /$} & $/ \operatorname{lnvz/}$ & $/ \mathrm{p} /$ & 3 & $50 \%$ \\
\hline & & & /lpvez/ & $/ \mathrm{p} /$ & 2 & $66,6 \%$ \\
\hline \multirow[t]{2}{*}{7} & \multirow[t]{2}{*}{ Love } & \multirow[t]{2}{*}{$/ 1 \Lambda \mathrm{v} /$} & $/ \operatorname{lpv} /$ & $/ \mathrm{p} /$ & 5 & $83,3 \%$ \\
\hline & & & $/ / \mathbf{p p} /$ & $/ \mathrm{p} /$ & 1 & $16,6 \%$ \\
\hline 8 & Much & $/ \mathrm{m} \wedge \mathrm{g} /$ & $/ \mathrm{mot} / /$ & $/ \mathrm{v} /$ & 3 & $50 \%$ \\
\hline
\end{tabular}

Table 9

Table Errors on Short Vowels 6

\begin{tabular}{|c|c|c|c|c|c|c|}
\hline No & Word & $\begin{array}{c}\text { Correct } \\
\text { Phonetic } \\
\text { Transcription }\end{array}$ & $\begin{array}{c}\text { Transcription } \\
\text { of Student's } \\
\text { Pronunciation }\end{array}$ & Errors & Freq & Percentage \\
\hline 1 & Good & $/ \mathrm{god} /$ & $/ \mathrm{gnd} /$ & $/ \mathrm{p} /$ & 3 & $50 \%$ \\
\hline
\end{tabular}

Table 10

Table Errors on Short Vowels 7

\begin{tabular}{|c|l|l|l|l|l|l|}
\hline No & Word & $\begin{array}{c}\text { Correct } \\
\text { Phonetic } \\
\text { Transcription }\end{array}$ & $\begin{array}{c}\text { Transcription } \\
\text { of Student's } \\
\text { Pronunciation }\end{array}$ & Errors & Freq & Percentage \\
\hline 1 & Not & $/ \mathrm{npt} /$ & $/ \mathrm{net} /$ & $/ \mathrm{e} /$ & 3 & $50 \%$ \\
\hline
\end{tabular}

\section{Mother Tongue}

The results of the interview with the second semester students of the English language study program at the Universitas Bhinneka PGRI. Mother tongue is one of the problems that can cause errors in English pronunciation. The sound pattern of the first language being transferred to the second language is indeed 
very difficult, many students complain that English is difficult to pronounce because they lack English speaking practice which makes the speculation that pronunciation in English is very difficult. The results of the interview research $80 \%$ of students answered that the mother tongue was the cause of the difficulty in pronouncing English correctly and the cause of frequent errors in English pronunciation.

\section{Personality}

The results of the second-semester student interview of the English language study program at the Universitas Bhinneka PGRI, researchers can conclude from all student answers that personal influence greatly affects $100 \%$ of students answering that personality greatly affects, students' errors in English pronunciation. Personality influences that often cause errors are students feeling insecure, afraid to make mistakes nervous when in front of crowds, and panic attacks. The results of the presentation that the researcher concluded from $40 \%$ of students' lack of confidence, $40 \%$ of students afraid of making mistakes, $50 \%$ of nervousness, and $10 \%$ of students who had panic attacks.

\section{Conclusion}

Based on the findings of the data analysis in the previous chapter, the researcher put forward several conclusions. From the analysis of pronunciation that has been obtained from questionnaires, interviews, and observations with oral tests, it was found that students experienced errors and the causes of errors in student pronunciation. The mistakes that students make when speaking English are vowels. and the causes of student difficulties in pronunciation are mother tongue and personality. The following are the errors of the secondsemester students of the English Language Study Program at the University of Bhinneka PGRI when speaking English and the causes of the pronunciation errors.

1. Vowels

There are 2 kinds of pronunciation errors on the vowels made by 2nd-semester students, they have errors in pronouncing long vowels and pronouncing short vowels. From the description of the results in the previous section, it is known that most of the students made pronunciation errors in the long vowel /3:/, /o:/,

/u:/, /i:/, and /a:/ with the highest number error in the long vowel /o:/. It was proven that around $66.6 \%$ of students pronounce / $/$ $\Lambda$ lwaiz/ for / $/$ "e $:$ lweiz/ in the word "always". Meanwhile, students made mistakes on short vowels $/ \mathrm{I} /, / \mathrm{\partial} /, / \mathrm{\Lambda} /, / \mathrm{p} /, / \mathfrak{m} /, / \mho /$, and $/ \varepsilon /$ with the highest number of errors on short vowels $/ \mathrm{N} /$. It was proven that around $83.3 \%$ of students said $/ \mathrm{lbv} /$ for $/{ }^{\circ e} / \Lambda \mathrm{v} /$ in the word "love". So, the results showed that most of the second-semester students of Universitas Bhinneka PGRI made pronunciation errors in the long vowel $/ \mathrm{s}: /$ and the short vowel $/ \Lambda /$.

\section{Mother Tongue}

Described in the previous section that the cause of student errors is the mother tongue. The results of the interview research $80 \%$ of students answered that the mother tongue was the cause of difficulty in pronouncing English correctly and the cause of frequent English pronunciation errors in 2nd-semester students at Universitas Bhinneka PGRI.

\section{Personality}

It is known from the previous description that in addition to the mother tongue that can cause pronunciation errors, namely the personality of all student answers, personal influence greatly affects $100 \%$ of student answers. Personality influences that often cause errors are students feel inferior, being 
afraid to make mistakes, nervous when in front of crowds, and having panic attacks. The results of the presentation that the researchers concluded from $40 \%$ of students lacked confidence, $40 \%$ of students were afraid of making mistakes, $50 \%$ were nervous, and $10 \%$ of students experienced panic attacks experienced by second- semester students at Universitas Bhinneka PGRI.

\section{Suggestion}

Based on the conclusions above, it is recommended that students be more confident in pronunciation and more practice to familiarize students to be more fluent in English pronunciation. Then, it would be better if the program students join the English club so that practice makes them regularly and makes them dare to speak in English so that they can help students get out of the zone of anxiety or fear in saying words in English so that they can speak English fluently. pronunciation with correct pronunciation. Students should also study hard and do more practicing pronunciation because that is the key to being able to communicate in English, students should not be shy about expressing their ideas, and students should not be afraid of making mistakes.

It is also recommended for students to learn more about English pronunciation through the you tube application or online learning. Then it is also recommended to the teacher. A teacher must motivate and stimulate students' opinions, it is very important to increase students' attention in learning English, especially on pronunciation so that students can speak English well and the teacher must be able to make teaching and the learning process fun so that students can enjoy it in learning English.

\section{References}

Hassan Al-Ahdal, A. A. M., Al-Hattami, A. A., Al-Awaid, S. A. A., \& Al-Mashaqba, N. J. H. (2015). Pronunciation for the Arab Learners of EFL: Planning for Better Outcomes. English Language Teaching, 8(10), 100-106. https://doi.org/10.5539/elt.v8n10p100

Ramasari, M. (2017). Students Pronounciation Error Made in. JET (Journal of English Teaching), 1(1), 3748. 